Şen, E. (2019). 1980-2008 yılları arasında yazılmış yerli çocuk tiyatrosu metinlerinin söz varlığı açısından incelenmesi. Ana Dili Eğitimi Dergisi, 7(1), 79-93.

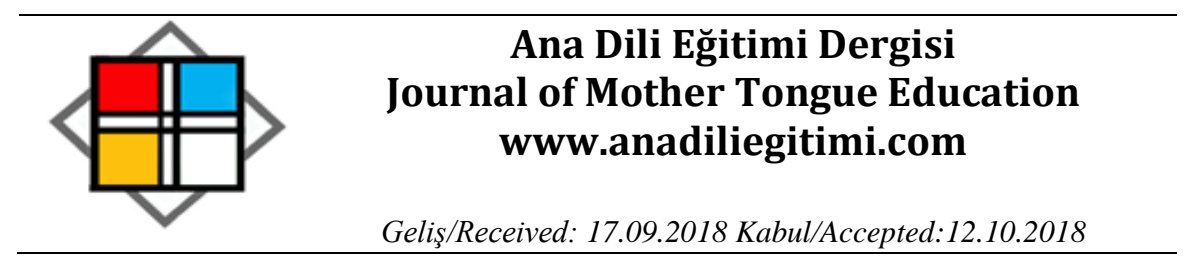

\title{
1980-2008 Yılları Arasında Yazılmış Yerli Çocuk Tiyatrosu Metinlerinin Söz Varlığı Açısından Incelenmesi* $^{*}$
}

\author{
Erhan ŞEN**
}

\section{Öz}

Çocuklara seslenen yazınsal türlerin incelenmesinde yapılacak öncelikle çalışmalardan biri söz varlığına dönük değerlendirmelerdir. Bu çalışmada da 1980-2008 yılları arasında yazılmış yerli çocuk tiyatrosu metinlerindeki söz varlığı öğeleri (sözcükler, özel adlar, ikilemeler, deyimler, atasözleri) belirlenmeye çalışımıştır. Nitel araştırma yöntemine dayalı bu çalışmada verilerin çözümlenmesi için içerik çözümlemesinden yararlanılmıştır. Çalışmada 100 yerli çocuk tiyatrosu metni incelenerek 100.000 sözcüklük bir havuz oluşturulmuştur. Bu sözcük havuzunda belirlenen farklı sözcük sayısı 7264'tür. Söz varlığı öğelerinden özel adlar en fazla sıklığa sahipken atasözlerinin sıklık düzeylerinin en alt düzeyde olduğu görülmüştür. Ancak bazı araştırmaların bulgularıyla karşılaştırıldığında bu metinlerin atasözü kullanımı yönünden yeterli bir sıklığa sahip olduğu söylenebilir. Geleneksel anlatılardaki karakterleri ve ulusal geçmişle ilgili kimlik, kurum ve mekânları simgeleyen özel adlar bu metinlerde önemli bir sıklık düzeyine sahiptir. İilemeler yönünden ise bu metinlerde çocuk tiyatrosu çalışmalarının temel amacını yansıtan bir seçimin egemen olduğu söylenebilir. Dayanışmanın önemini vurgulayan ya da birlikte güçlüklerin üstesinden gelme iletisini içeren ikilemelerin sıklık düzeyinin yüksek olduğu görülmüştür.

Anahtar Kelimeler: Çocuk edebiyatı, çocuk tiyatrosu, tiyatro metni, söz varlığı, içerik çözümlemesi

\section{An Analysis on the Native Children's Theater Texts Written between 1980 and 2008 in Terms of the Vocabulary}

\begin{abstract}
One of the studies to be done in order to analysis the literary genres that written to children are the evaluations about vocabulary. In this study, it was tried to determine the vocabulary (words, special names, reiterative, idioms, proverbs) in the native children theatrical texts between 1980 and 2008. In the study based on qualitative research method, content analysis was used to analyze the data. In the study, 100 native children's theater texts were examined and a word pool of $\mathbf{1 0 0 . 0 0 0}$ was composed in this study. The number of different words that determined in this word pool is 7264. It was seen that the frequency levels of the proverbs are at the lowest level, while the private names have the highest frequency. However, when compared with the findings of some researches, it can be said that these texts have a sufficient frequency in terms of the proverbs. The special names in the texts that symbolizing the identities, institutions and places related to the traditional characters and the national past have an important frequency level. It can be said that the level of frequency of the reiterative which emphasize the importance of the cooperation is high. From this point of view, it can be said that the reiterative reflect the basic aim of children theatrical activities.
\end{abstract}

Keywords: Children's literature, children's theatre, theatrical text, vocabulary, content analysis

\footnotetext{
*Bu çalışma “1980'den Günümüze Çocuk Edebiyatı Alanında Yazılmış Yerli Çocuk Tiyatrosu Metinlerinin Söz Varlığı Üzerine Bir İnceleme” başlıklı yüksek lisans tezinden üretilmiştir.

${ }^{* *}$ Dr. Öğr. Üyesi, Van Yüzüncü Yıl Üniversitesi, Eğitim Fakültesi, Türkçe ve Sosyal Bilimler Eğitimi Bölümü, Van, erhansen@yyu.edu.tr, ORCID: 0000-0001-7678-812X
} 


\section{Giriş}

Söz varlığı öğeleri anadili eğitiminde bir dilin anlatım inceliklerini ya da olanaklarını çocuğa duyumsatma gibi önemli işleve sahiptir (Çetinkaya, 2007; Mert, 2009; Sever, 2013). Çocuğun dilsel gelişiminde, özellikle söz varlığının zenginleşmesinde, çocuk edebiyatı yapıtlarının işlevsel bir rolü vardır (Aslan, 2006; Demirel, Uludağ, Tozlu, Seven ve Çeçen, 2010; Sever, 2013). Dolayısıyla çocuklara seslenen dilsel metinlere dönük yapılacak ilk çalışmalardan biri söz varlığı incelemeleridir.

Bir dilin temelini sözcükler oluşturur. Sözcük hazinesinin zenginliğiyle bireyin kendini ifade biçimi arasında bir koşutluk vardır. Bireyin kavram dünyası ne denli yoksullaşırsa düşünce tembelliği de o oranda artar (Yaman, 2004, s. 101). Sözcüğün ne olduğuna dönük araştırmacıların/uzmanların kesin bir uzlaşıya vardıklarını söylemek güçtür. Ancak toparlayıcı bir bakış açısıyla sözcük "aynı dili konuşan bireylerin belleğinde benzer olgu, durum, olay ya da düşünceye göndermede bulunan; bireyler arasındaki iletişimi sağlayan; nesne ya da varlığı karşılayan; ses ya da ses öbeğinden oluşan; soyut ya da somut anlamlı dilsel birimdir" (Aksan, 2003, s. 57; Ediskun, 2005, s. 87; Korkmaz, 1992, s. 100; Özdemir, 2000, s. 25; Türkçe Sözlük, 2005, s. 1130; Vardar, 1980, s. 134).

Söz varlığı ise bir dilin bütün sözcükleri, bir kişinin ya da bir topluluğun söz dağarcığında yer alan sözcüklerin toplamıdır (Korkmaz, 1992, s. 100). Söz varlığını dildeki sözcüklerin tümü, terimler, yabancı kökenli sözcükler, atasözleri, deyimler, kalıp sözler ve birtakım özdeyişler oluşturur (Aksan, 2006, s. 13).

Bireylerde söz varlığı etkin ve edilgin olmak üzere iki boyutta görülür. Bireyin yazılı ya da sözlü anlatımlarında rahat ve kolayca kullandığı sözcükler etkin; ara sıra duyulan ve bir metinde karşılaşıldığı zaman anlaşılmasına karşın sözcede kullanılmayan sözcükler ise edilgin söz varlığını temsil eder (Günay, 2007, s. 30; Karakuş, 2000, s. 128). Dil ve edebiyat öğretiminin ana hedeflerinden biri de çocuğun edilgin söz varlığını devindirmek, etkin söz varlığını zenginleştirmektir.

Türkiye'de söz varlı̆ıına dönük birçok çalışmanın yapıldığı görülmektedir. Öğretilecek sözcüklerin belirlenmesine dönük listeler hazırlanmış (Aksoy, 1936; Pars ve Pars, 1954); farklı yaş grubundaki bireylerin sözcük hazinesi incelenmiş (Çiftçi, 1991; Harıt, 1972; Karadağ, 2005; Kurudayıoğlu, 2005); Türkçe ders kitapları (Büyükhellaç, 2014; Yalçın S. K., 2005); çocuk edebiyatı alanında yazılmış olaya dayalı metinler (Baş, 2006) ya da farklı yaş düzeyine seslenen yazarların yapıtları (Aydın, 2016; Mete, 2016; Özbaşı, 2016; Sever ve Karagül, 2014; Uzun, 2010) söz varlı̆ı öğeleri açısından incelenmiştir. Bu çalışmalar dışında Türkiye'de söz varlığı alanında yapılmış küçük ölçekli çalışmalar vardır. Ancak önem ve kapsam alanının genişliğinden ötürü bu çalışmalara değinmenin yeterli olduğu düşünülmektedir. 
Dil ve edebiyat öğretimi açısından tiyatro metinleri önemli bir yazınsal türdür. Türkçe Dersi Öğretim Programında da tiyatro metinlerine tüm ders kitaplarında (1-8. sınıflar) yer verilmesi önerilmektedir (Türkçe Dersi Öğretim Programı, 2018, s. 18).

Başlı başına sanatsal bir etkinlik olan çocuk tiyatrosu çocuğun estetik ve karakter gelişimine, sorumluluk bilinci kazanmasına, onda dil kaygısı, güzel ve doğru konuşma gibi yeni becerilerin oluşmasına yardım eder (Nutku, 1998, s. 141-142). Tiyatro etkinliklerinde çocuklar açısından istenen sonucun elde edilmesi için metnin kurgulanmasından başlayıp tüm aşamalarda gereken özen gösterilmelidir. Çocuk oyunlarında diğer öğeler kadar dilsel düzenleme de büyük önem taşır. Çünkü tiyatro çalışmaları için öncelikle bir metne gereksinim vardır (Demirel ve ark., 2010, s. 275; Şimşek, 2005, s. 13).

Oyunların dilsel düzenlemesi kaynağını gündelik yaşamdan almalı, yanlışsı bir yapıya sahip olmalı ve çocukların dillerini tanımalarına yardım etmelidir (Kuyumcu, 2007, s. 31). Örneğin; "düş önüme", "arkama düş", "kafanı topla” gibi çift anlamlı sözcüklerle yapılan dilsel oyunlar çocukların bu yönden yetkinleşmelerine hizmet eder (Kuyumcu, 2007, s. 207). Böylece çocuk soyut olan dili tanıma fırsatı bulur, sözcüklerin anlamları üzerinde düşünerek dili doğru ve yanlış kullanmanın ayrımına varır (Kuyumcu, 2000, s. 58).

Sözcükler oyunun gövdesini oluşturur (Craig; Akt. Nutku, 2001, s. 122). Tiyatro metinlerinde iletilerin, olayların, durumların izleyiciye aktaran temel öğe sözcüklerdir. Tiyatro metinlerinde konuşma örgüsü sözcüklerin ya da başka deyişle söz varlığının temel taşıyıcısıdır. Konuşma örgüsü "diyalog" kavramıyla açıklanır. Konuşma örgüsü bir yandan sahnedeki devinimi beslerken öte yandan da izleyiciyi gerçekleşenlere ilişkin bilgilendirir. Bu konuda kitap okuruyla tiyatro izleyicisinin farklı ayrıcalıkları vardır. Tiyatro izleyicisi, bir kitap okuru gibi, oyunu anlamak için tekrar tekrar başa dönüp dilsel düzenlemeyi irdeleme olanağına sahip değildir. Bu nedenle konuşma örgüsü şu özellikleri taşımalıdır (Nutku, 2001, s. 184-187):

\footnotetext{
> Öncelikle ekonomik, açık ve anlaşılır olmalıdır.

Kolay konuşabilecek bir biçimde hazırlanmalı dile zor gelmemelidir.

> Yalın konuşma biçimiyle her tümce oyuna bir gelişim sağlamalıdır.

> Karşılıklı konuşma alışagelmiş günlük konuşmadan daha ekonomik olmalı ve günlük yaşamda kullandığımız gereksiz sözcüklere yer verilmemelidir.

$>\quad$ Oyunun türüne uyacak biçimde ve oyunun geçtiği dönemi yansıtan dil örgüsü kullanılmalıdır.
}

Türk edebiyatının çocuk tiyatrosu açısından zengin olduğu söylenemez. Dolayısıyla çocukların ilgisini çeken, onların yaş düzeylerine uygun, dünyalarını yansıtan ya da oynayabilecekleri bir oyun 
seçebilmek öğretmenler için kolay değildir (Kuyumcu, 2007, s. 58; Nas, 2002, s. 362). Ayrıca var olan oyunlar da tüm yönleriyle bilimsel açıdan yeterince incelenmemiştir (Demirel ve ark., 2010, s. 276; Yalçın ve Aytaş, 2005, s. 222). Bu çalışmanın yerli çocuk tiyatrosu metinlerinin söz varlığını ortaya koyma ve bu alanda metinler üretecek farklı öznelere (yazar, eğitimci, uzman...) kılavuzluk etme açısından bir boşluğu doldurabileceği söylenebilir.

\section{Yöntem}

\section{Araştırmanın Modeli}

Bu çalışma nitel araştırma yöntemlerinden durum çalışmasına dayanmaktadır. Bununla birlikte durum çalışması desenlerinden "iç içe geçmiş tek durum deseni" kullanılmış. Tek bir durum içinde çoğu kez birden fazla alt tabaka ya da birim olabilir. Bu durumda birden fazla analiz birimi söz konusu olacaktır. Buradaki ayrım, bir durum çalışmasının ilgili durumu, bütüncül ve tek bir ünite olarak ele almasına veya bir durum içinde olabilecek birden fazla alt birime yönelmesine ilişkindir (Yıldırım ve Şimşek, 2016). Çalışmada incelenen çocuk tiyatrosu metinlerindeki söz varlığı bir durum olarak ele alınırken söz varlığı öğeleri de birer birim olarak ayrı ayrı değerlendirilmiştir.

\section{Araştırmanın İnceleme Nesneleri}

Bu çalışmanın araştırma nesnelerini 1980-2008 yılları arasında yazılmış 100 yerli çocuk tiyatrosu metninin başından, ortasından ve sonundan rastlantısal biçimde seçilen 100.000 sözcüklük havuz oluşturmaktadır.

\section{Verilerin Kaynağı ve Toplanması}

Verilerin toplanmasının ilk aşamasında çözümlenecek 100 yerli çocuk tiyatrosu metni literatür taraması ve uzman görüşü alınarak belirlenmiştir. Söz konusu metinlere ödünç alma, satın alma ya da fotokopiyle çoğaltma gibi farklı yollarla ulaşılmıştır. Ardından söz varlığını oluşturan başlıklar belirlenmiştir.

\section{Verilerin Çözümlenmesi}

Bu çalışmada içerik çözümlemesi türlerinden olan "kategorisel çözümleme tekniği"ne başvurulmuştur. İçerik çözümlemesi bir metnin bazı sözcüklerinin daha küçük içerik kategorileriyle belirli kurallara dayalı kodlamalarla özetlenen dizgesel ve tekrarlanabilir bir tekniktir (Büyüköztürk, Akgün, Karadeniz, Demirel ve Çakmak, 2010, s. 269). “Kategorisel çözümleme tekniği”"nde genellikle belli bir ileti önce birimlere bölünür, ardından bu birimler önceden saptanmış ölçütlere göre kategoriler halinde gruplandırılır ve kategorilerin sıklığı (frekansı) hesaplanır (Tavşancıl ve Aslan, 2001). 
İçerik çözümlemesinin ilk aşamasında çözümleme birimi olarak ana ile alt kategoriler belirlenir ve tanımlanır. İkinci aşamada ise çözümlemelerin yapılacağı bağlam birimine (tümce, paragraf ya da tüm metin) karar verilir (Yıldırım ve Şimşek, 2016). Çalışmada çözümleme birimi olarak "sözcükler, özel adlar, ikilemeler, deyimler ve atasözleri" seçilmiştir. Yerli çocuk tiyatrosu metinlerindeki söz varlığı öğeleri birer birer kodlanmış ve sıklık düzeyleri kaydedilmiştir. Çalışmanın ana kategorisini "söz varlığı"; alt kategorileri ise "sözcükler, özel adlar, ikilemeler, deyimler ve atasözü" oluşturmaktadır.

\section{İşlem Basamakları}

1. Toplanan verilerin çözümlenmesi ve sözcük listelerinin oluşturulmasında sözcükleri sıklık derecelerine göre sıralayan ve sıklık istatistiği yapan "Simple Concordance Program 4.09" (www.textworld.com/scp) kullanılmıştır.

2. Yerli çocuk tiyatrosu metinlerindeki konuşma örgülerinden -başından, ortasından, sonundan - eşit olmak koşuluyla 1000'er sözcük alınmıştır. Oluşturulan 100.000'lik sözcük havuzu bilgisayar ortamına aktarılmıştır.

3. Çalışmada kullanılan program sözcükleri tek tek işlediği için metinlerdeki bileşik sözcükler, ikilemeler, deyimler ve atasözlerini oluşturan sözcükler arasına artı (+) işareti konulmuştur. (Örneğin; "bir+türlü", "güle+güle”, "canı+sıkılmak", "sakla+samanı+gelir+zamanı")

4. Sözcük havuzundaki söz varlığı öğeleri üzerinde daha ayrıntılı çözümleme için değişik imler kullanılmıştır. Özel adların başına "*” işareti konulmuştur. (Örneğin; “*Atatürk, *Keloğlan”). Ayrıca metinlerdeki çok basamaklı sayılar birleşik yazılmıştır. [Örneğin; ("bindokuzyüzondokuz")].

5. Deyimler "-mak, -mek" mastar ekleriyle; “-mı, -mi, -mu, -mü" soru edatları ayrı ayrı değil de bir bütün olarak "mı+mi+mu+mü"; "da, de" bağlacı ise "da+de" biçiminde yazılmıştır.

6. Eylemlerin çekim ekleri atılmış. Bunların yerine "-“ işareti konulmuştur. (Örneğin; okuyor/oku-, sattı/sat-). Eylemlerin anlam farklılıklarını belirtmek amacıyla Türk Dil Kurumunun hazırladığı Türkçe Sözlük (2005) kullanılmıştır. Sözcükler arasındaki anlam farklılıları yay ayraç içinde verilmiştir. [Örneğin; "çal- (müzik aleti)”; "saz (müzikaleti); saz (kamış); yüz (çehre); yüz (sayı) koyun (kucak)"]

7. Kalıcı ad yapmayan zarf-fiil, sıfat-fiil ekleri sözcüklerden silinmiştir. Örneğin; "konuşacak, konuşan, konuşarak." Ancak kalıcı ad durumuna gelen sözcüklerdeki ekler olduğu gibi bırakılmıştır. Örneğin; "geçmiş (mazi), ermiş (kendini Tanrı'ya adamış kimse) biçiminde ele alınmıştır.

8. Yerli çocuk tiyatrosu metinlerinde yer alan farklı sözcük sıklıkları, özel adlar, deyimler, ikilemeler ve atasözleri listeleri hazırlanmış ve bunların aktarıldığı tablolar oluşturulmuştur. Tablolardan hareketle çözümlemeler yapılmış ve yorumlar gerçekleştirilmiştir. 
9. Yerli çocuk tiyatrosu metinlerinde yer alan deyimler ve atasözleri Aksoy'un hazırlamış olduğu Atasözleri ve Deyimler Sözlüğü 1-2 (1998) ve Parlatır tarafından hazırlanan Atasözleri ve Deyimler Sözlüğü I-II (2008) kaynakları temel alınarak belirlenmiştir.

10. "Simple Concordance Program 4.09" adlı programa ilişkin terimlerin Türkçe karşılığı için Baş (2006) tarafından hazırlanan doktora tezinden yararlanılmıştır. "Sözcük Sıklığı", bir sözcüğün metin içindeki sıklığını; "Toplam Farklı sözcük " kullanılan toplam farklı sözcükleri; "Toplam Sözcük", sözcüklerin toplam kullanımını; "Farklı Sözcük Yüzdeliği”, farklı sözcüğün toplam farklı sözcük içindeki kullanım oranını, "Toplam Sözcük Yüzdeliği" ise farklı sözcüğün toplam sözcük içindeki oranını göstermektedir.

\section{Bulgular}

Bu bölümde çalışmanın veri kaynağını oluşturan yerli çocuk tiyatrosu metinlerindeki söz varlığı (sözcükler, özel adlar, ikilemeler, deyimler ve atasözleri) öğeleriyle ilgili bulgular verilmiştir. Söz konusu bulgular tablolar yardımıyla somutlaştırılmıştır.

Tablo 1. Yerli çocuk tiyatrosu metinlerinde yer alan ilk 20 sözcügün sıklık derecesi

\begin{tabular}{|c|c|c|c|c|c|c|}
\hline Sira No & $\begin{array}{l}\text { Sözcük } \\
\text { Sıklığı }\end{array}$ & $\begin{array}{c}\text { Farklı } \\
\text { Sözcük }\end{array}$ & $\begin{array}{l}\text { Toplam } \\
\text { Sözcük }\end{array}$ & $\begin{array}{c}\text { Farklı Sözcük } \\
\text { Yüzdeliği }\end{array}$ & $\begin{array}{c}\text { Toplam Sözcük } \\
\text { Yüzdeliği }\end{array}$ & Kullanılan Sözcük \\
\hline 1. & 2457 & 1 & 2457 & 0,013767 & 2,457 & da, de (bağlaç) \\
\hline 2. & 2361 & 1 & 2361 & 0,013767 & 2,361 & ol- \\
\hline 3. & 2289 & 1 & 2289 & 0,013767 & 2,289 & bir \\
\hline 4. & 2275 & 1 & 2275 & 0,013767 & 2,275 & ben (zamir) \\
\hline 5. & 1865 & 1 & 1865 & 0,013767 & 1,865 & ne \\
\hline 6. & 1844 & 1 & 1844 & 0,013767 & 1,844 & $\mathrm{ml}, \mathrm{mi}, \mathrm{mu}, \mathrm{mü}$ \\
\hline 7. & 1706 & 1 & 1706 & 0,013767 & 1,706 & bu \\
\hline 8. & 1262 & 1 & 1262 & 0,013767 & 1,262 & sen \\
\hline 9. & 1030 & 1 & 1030 & 0,013767 & 1,03 & biz \\
\hline 10 & 1026 & 1 & 1026 & 0,013767 & 1,026 & 0 \\
\hline 11 & 974 & 1 & 974 & 0,013767 & 0,974 & de- \\
\hline 12 & 921 & 1 & 921 & 0,013767 & 0,921 & çok \\
\hline 13 & 877 & 1 & 877 & 0,013767 & 0,877 & gel- \\
\hline 14 & 833 & 1 & 833 & 0,013767 & 0,833 & siz \\
\hline 15 & 801 & 1 & 801 & 0,013767 & 0,801 & yap- \\
\hline 16 & 742 & 1 & 742 & 0,013767 & 0,742 & bak- \\
\hline 17 & 717 & 1 & 717 & 0,013767 & 0,717 & ama \\
\hline 18 & 673 & 1 & 673 & 0,013767 & 0,673 & iste- \\
\hline 19 & 670 & 1 & 670 & 0,013767 & 0,67 & var \\
\hline 20 & 601 & 1 & 601 & 0,013767 & 0,601 & şey \\
\hline Toplam & 25924 & 20 & 25924 & 0,27534 & 25,924 & \\
\hline
\end{tabular}

Çalışma kapsamında oluşturulan 100.000 'lik sözcük havuzunda toplam 7264 farklı sözcük belirlenmiştir. Tablo 1'de yerli çocuk tiyatrosu metinlerinde en sık kullanılan ilk 20 sözcüğün toplam sözcük havuzu (100.000) içindeki dağılımı gösterilmektedir. Tabloda sıklık derecesine göre ilk 20 sözcüğün toplam sayısı 25924'tür. Farklı sözcük sayısı ise 20 'dir. Farklı sözcük yüzdeliği 0,27534 olup toplam söz varlığı yüzdeliği 25,924'tür. Yerli çocuk tiyatrosu metinlerinde en sık kullanılan sözcük 
"da, de” bağlacıdır (f: 2457). "Ol-“ eylemi (f:2361) sıklık bakımından ikinci sıradadır. Üçüncü sırayı ise "bir" (f: 2289) sözcüğü almaktadır. Illk üç sözcük için yapılan değerlendirmeler diğer sözcüklerin tümü için aynı biçimde sürdürülebilir.

Tablo 2. Yerli çocuk tiyatrosu metinlerinde yer alan söz varlığı öğelerinin sayısal dağılımı

\begin{tabular}{|l|c|c|c|}
\hline \multicolumn{1}{|c|}{ Söz varlığı Öğeleri } & Toplam & Farklı & Yinelenme Oranı \\
\hline Özel adlar & 3099 & 886 & 3,49 \\
\hline Deyimler & 2289 & 947 & 2,41 \\
\hline İkilemeler & 566 & 259 & 2,18 \\
\hline Atasözleri & 16 & 14 & 1,14 \\
\hline
\end{tabular}

Tablo 2'de yerli çocuk tiyatrosu metinlerinde yer alan söz varlığı öğelerinin dağlımı gösterilmektedir. Buna göre yerli çocuk tiyatrosu metinlerinde toplam özel ad sayısı 3099, farklı özel ad sayısı 886; toplam deyim sayısı 2289, farklı deyim sayısı 947; toplam ikileme sayısı ise 566 , farklı ikileme sayısı 259; toplam atasözü sayısı 16, farklı atasözü sayısı 14'tür. Toplamda ilk sırayı özel adlar (f:3099) alırken farklıık sıklı̆̆ yönünden ise deyimler (f:947) ilk sıradadır. Bu yönden deyimlerin diğer öğelerden daha fazla çeşitlilik gösterdiği söylenebilir. Toplam kullanım sıklığı ile toplam farklı kullanım sıklığının oranları alındığında söz konusu söz varlığı öğelerinin yinelenme oranları elde edilebilir. Dolayısıyla özel bir adın yaklaşık olarak (3099/886) 3,49; bir deyimin (2289/947) 2,41; bir ikilemenin (566/259) 2,18; bir atasözünün (16/14) ise 1,14 kere yinelendiği söylenebilir.

Tablo 3. Yerli çocuk tiyatrosu metinlerinde belirlenen ilk 50 özel adın sıklık derecesi

\begin{tabular}{|c|c|c|c|c|}
\hline Sira & Özel Adın Sıklığı & Özel Ad & $\begin{array}{c}\text { Farklı Özel Ad } \\
\text { Yüzdeliği }\end{array}$ & $\begin{array}{c}\text { Toplam Özel Ad } \\
\text { Yüzdeliği }\end{array}$ \\
\hline 1. & 119 & Keloğlan & 13,43115 & 3,839948 \\
\hline 2. & 79 & Karagöz & 8,916479 & 2,549209 \\
\hline 3. & 46 & Allah & 5,191874 & 1,48435 \\
\hline 4. & 32 & Prenses & 3,611738 & 1,032591 \\
\hline 5. & 31 & Atatürk & 3,498871 & 1,000323 \\
\hline 6. & 28 & Sürmeli & 3,160271 & 0,903517 \\
\hline 7. & 28 & Tanrı & 3,160271 & 0,903517 \\
\hline 8. & 25 & Nazik & 2,82167 & 0,806712 \\
\hline 9. & 25 & Türkiye & 2,82167 & 0,806712 \\
\hline 10. & 23 & Hacıcavcav & 2,595937 & 0,742175 \\
\hline 11. & 23 & Hacivat & 2,595937 & 0,742175 \\
\hline 12. & 23 & Hoca & 2,595937 & 0,742175 \\
\hline 13. & 22 & Hatice & 2,48307 & 0,709906 \\
\hline 14. & 20 & Tamburi & 2,257336 & 0,645369 \\
\hline 15. & 19 & Hoca Efendi & 2,14447 & 0,613101 \\
\hline 16. & 19 & Kırıkçatal & 2,14447 & 0,613101 \\
\hline 17. & 18 & Ankara & 2,031603 & 0,580833 \\
\hline 18. & 18 & Aslan & 2,031603 & 0,580833 \\
\hline 19. & 18 & Devol & 2,031603 & 0,580833 \\
\hline 20. & 18 & Memiş & 2,031603 & 0,580833 \\
\hline 21. & 18 & Türk & 2,031603 & 0,580833 \\
\hline 22. & 18 & Ufaklık & 2,031603 & 0,580833 \\
\hline 23. & 18 & Yüce Hakan & 2,031603 & 0,580833 \\
\hline 24. & 17 & Mavi Pullu Balık & 1,918736 & 0,548564 \\
\hline 25. & 16 & Anadolu & 1,805869 & 0,516296 \\
\hline
\end{tabular}




\begin{tabular}{|c|c|c|c|c|}
\hline Sıra & Özel Adın Sıklığı & Özel Ad & $\begin{array}{c}\text { Farklı̈̈zel Ad } \\
\text { Yüzdeliği }\end{array}$ & $\begin{array}{c}\text { Toplam Özel Ad } \\
\text { Yüzdeliği }\end{array}$ \\
\hline 26. & 16 & Cumhur & 1,805869 & 0,516296 \\
\hline 27. & 16 & Tontiş & 1,805869 & 0,516296 \\
\hline 28. & 15 & Ayşe & 1,693002 & 0,484027 \\
\hline 29. & 15 & Kral & 1,693002 & 0,484027 \\
\hline 30. & 15 & Mavi Bekçi & 1,693002 & 0,484027 \\
\hline 31. & 15 & Murat & 1,693002 & 0,484027 \\
\hline 32. & 15 & Palyaço & 1,693002 & 0,484027 \\
\hline 33. & 15 & Tavşan & 1,693002 & 0,484027 \\
\hline 34. & 15 & Tilki & 1,693002 & 0,484027 \\
\hline 35. & 14 & Afacan & 1,580135 & 0,451759 \\
\hline 36. & 14 & Ariel & 1,580135 & 0,451759 \\
\hline 37. & 14 & Gümüşkepçe & 1,580135 & 0,451759 \\
\hline 38. & 14 & İzmir & 1,580135 & 0,451759 \\
\hline 39. & 14 & Mustafa Kemal Paşa & 1,580135 & 0,451759 \\
\hline 40. & 13 & Ali & 1,467269 & 0,41949 \\
\hline 41. & 13 & Kara Oduncu & 1,467269 & 0,41949 \\
\hline 42. & 13 & Küçük Kardeş & 1,467269 & 0,41949 \\
\hline 43. & 12 & Bayan Missi & 1,354402 & 0,387222 \\
\hline 44. & 12 & Devgücü & 1,354402 & 0,387222 \\
\hline 45. & 12 & Fırıncı Baba & 1,354402 & 0,387222 \\
\hline 46. & 12 & Kocaçam & 1,354402 & 0,387222 \\
\hline 47. & 12 & Vezir & 1,354402 & 0,387222 \\
\hline 48. & 11 & Bay Zengimo & 1,241535 & 0,354953 \\
\hline 49. & 11 & Lale & 1,241535 & 0,354953 \\
\hline 50. & 11 & Maestro & 1,241535 & 0,354953 \\
\hline Toplam & 1060 & \multicolumn{1}{|c|}{} & 119,638826 & 34,204587 \\
\hline
\end{tabular}

Tablo 3'te yerli çocuk tiyatrosu metinlerinde yer alan ilk 50 özel ad verilmektedir. Buna göre Keloğlan (f: 119) ilk; Karagöz (f:79) ikinci; Allah (f:46) üçüncü; Prenses (f:32) dördüncü; Atatürk (f:31) beşinci sırada yer almaktadır. Tabloda yer alan diğer özel adlar için de benzer değerlendirmeler yapılabilir.

Tablo 4. Yerli çocuk tiyatrosu metinlerinde yer alan ilk 50 deyimin sıklık derecesi

\begin{tabular}{|c|c|c|c|c|}
\hline Sira & Deyimin Siklığ 1 & Deyimler & $\begin{array}{c}\text { Farklı Deyim } \\
\text { Yüzdeliği }\end{array}$ & $\begin{array}{c}\text { Toplam Deyim } \\
\text { Yüzdeliğ }\end{array}$ \\
\hline 1. & 80 & Hoş gel- & 0.105597 & 3.494976 \\
\hline 2. & 50 & Özür dilemek & 0.105597 & 2.18436 \\
\hline 3. & 47 & Hoşça kal- & 0.105597 & 2.053298 \\
\hline 4. & 41 & Sağ ol & 0.105597 & 1.791175 \\
\hline 5. & 35 & Merak etmek & 0.105597 & 1.529052 \\
\hline 6. & 33 & Söz vermek & 0.105597 & 1.441678 \\
\hline 7. & 32 & Ne olur & 0.105597 & 1.39799 \\
\hline 8. & 30 & Başına gelmek & 0.105597 & 1.310616 \\
\hline 9. & 27 & Aklına gelmek & 0.211193 & 2.359109 \\
\hline 10. & 27 & İşe yaramak & 0.211193 & 2.359109 \\
\hline 11. & 25 & Kim bilir & 0.211193 & 2.18436 \\
\hline 12. & 25 & Sözünü etmek & 0.211193 & 2.18436 \\
\hline 13. & 24 & İzin vermek & 0.105597 & 1.048493 \\
\hline 14. & 21 & Haber vermek & 0.105597 & 0.917431 \\
\hline 15. & 20 & Canı sikılmak & 0.211193 & 1.747488 \\
\hline 16. & 20 & Şaka yapmak & 0.211193 & 1.747488 \\
\hline 17. & 18 & Aç kalmak & 0.31679 & 2.359109 \\
\hline
\end{tabular}




\begin{tabular}{|c|c|c|c|c|}
\hline Sira & Deyimin Sıklı̆̆ı & Deyimler & $\begin{array}{l}\text { Farklı Deyim } \\
\text { Yüzdeliği }\end{array}$ & $\begin{array}{l}\text { Toplam Deyim } \\
\text { Yüzdeliği }\end{array}$ \\
\hline 18. & 18 & Alay etmek & 0.31679 & 2.359109 \\
\hline 19. & 18 & Yok canım & 0.31679 & 2.359109 \\
\hline 20. & 17 & Dalga geçmek & 0.105597 & 0.742682 \\
\hline 21. & 15 & Balık tutmak & 0.105597 & 0.655308 \\
\hline 22. & 14 & Ceza vermek & 0.211193 & 1.223242 \\
\hline 23. & 14 & Ders çalışmak & 0.211193 & 1.223242 \\
\hline 24. & 13 & Adam olmak & 0.31679 & 1.703801 \\
\hline 25. & 13 & Yolunu bulmak & 0.31679 & 1.703801 \\
\hline 26. & 13 & Zarar vermek & 0.31679 & 1.703801 \\
\hline 27. & 12 & Cevap vermek & 0.211193 & 1.048493 \\
\hline 28. & 12 & Hoşuna gitmek & 0.211193 & 1.048493 \\
\hline 29. & 11 & Boş vermek & 0.31679 & 1.441678 \\
\hline 30. & 11 & Kendine gelmek & 0.31679 & 1.441678 \\
\hline 31. & 11 & Yola çıkmak & 0.31679 & 1.441678 \\
\hline 32. & 10 & Eline geçmek & 0.422386 & 1.747488 \\
\hline 33. & 10 & Fark etmek & 0.422386 & 1.747488 \\
\hline 34. & 10 & Kusura bakmamak & 0.422386 & 1.747488 \\
\hline 35. & 10 & Vay canına & 0.422386 & 1.747488 \\
\hline 36. & 9 & Dayak yemek & 0.105597 & 0.393185 \\
\hline 37. & 8 & Aklı başına gelmek & 0.739176 & 2.446483 \\
\hline 38. & 8 & Allah Allah & 0.739176 & 2.446483 \\
\hline 39. & 8 & El ele vermek & 0.739176 & 2.446483 \\
\hline 40. & 8 & Elinden gelmek & 0.739176 & 2.446483 \\
\hline 41. & 8 & Hoş bulmak & 0.739176 & 2.446483 \\
\hline 42. & 8 & Sahip çıkmak & 0.739176 & 2.446483 \\
\hline 43. & 8 & Zamanı geçmek & 0.739176 & 2.446483 \\
\hline 44. & 7 & Canı istemek & 0.95037 & 2.752294 \\
\hline 45. & 7 & Ele geçirmek & 0.95037 & 2.752294 \\
\hline 46. & 7 & Geri vermek & 0.95037 & 2.752294 \\
\hline 47. & 7 & Ha şöyle & 0.95037 & 2.752294 \\
\hline 48. & 7 & İçi yanmak & 0.95037 & 2.752294 \\
\hline 49. & 7 & Karşı çıkmak & 0.95037 & 2.752294 \\
\hline 50. & 7 & Olan biten & 0.95037 & 2.752294 \\
\hline
\end{tabular}

Tablo 4'te yerli çocuk tiyatrosu metinlerinde bulunan ve sıklık derecesine göre dizilmiş ilk 50 deyim gösterilmektedir. Bu tabloya göre hoş gel- (hoş geldiniz/hoş geldin) (f:80) birinci; "özür dilemek” (f:50) ikinci; "hoşça kal-“ (f:40) üçüncü sırada yer almaktadır. Sırasıyla Tablodaki tüm deyimler için de benzer değerlendirmeler yapılabilir. Bununla birlikte "el", "baş", "akıl" sözcükleriyle yapılan deyimlerin ağırlıkta olduğu ve "ders çalışmak" (f:14) deyiminin sıklık açısından yoğun olduğu söylenebilir.

Tablo 5. Yerli çocuk tiyatrosu metinlerinde yer alan ilk 50 ikilemenin sıklık derecesi

\begin{tabular}{|c|c|c|c|c|}
\hline Sira & İkilemelerin sıklığı & $\begin{array}{l}\text { Kullanılan } \\
\text { Deyimler }\end{array}$ & $\begin{array}{c}\text { Farklı İkileme } \\
\text { Yüzdeliği }\end{array}$ & $\begin{array}{c}\text { Toplam İileme } \\
\text { Yüzdeliği }\end{array}$ \\
\hline 1. & 40 & güle güle & 0.3861 & 7.067138 \\
\hline 2. & 27 & el ele & 0.3861 & 4.770318 \\
\hline 3. & 19 & kendi kendine & 0.3861 & 3.35689 \\
\hline 4. & 11 & okuma yazma & 0.772201 & 3.886926 \\
\hline 5. & 11 & pırıl pırıl & 0.772201 & 3.886926 \\
\hline 6. & 9 & yavaş yavaş & 0.3861 & 1.590106 \\
\hline 7. & 8 & bir iki & 1.930502 & 7.067138 \\
\hline
\end{tabular}




\begin{tabular}{|c|c|c|c|c|}
\hline Sira & İkilemelerin sıklığı & $\begin{array}{l}\text { Kullanılan } \\
\text { Deyimler }\end{array}$ & $\begin{array}{|cc|}\text { Farklı } & \text { İkileme } \\
\text { Yüzdeliği }\end{array}$ & $\begin{array}{c}\text { Toplam } \\
\text { Yüzdeliği }\end{array}$ \\
\hline 8. & 8 & bol bol & 1.930502 & 7.067138 \\
\hline 9. & 8 & güzel güzel & 1.930502 & 7.067138 \\
\hline 10. & 8 & mışıl mışıl & 1.930502 & 7.067138 \\
\hline 11. & 8 & sabah sabah & 1.930502 & 7.067138 \\
\hline 12. & 7 & tek tek & 1.158301 & 3.710247 \\
\hline 13. & 7 & vah vah & 1.158301 & 3.710247 \\
\hline 14. & 7 & yan yana & 1.158301 & 3.710247 \\
\hline 15. & 6 & doğru dürüst & 1.544402 & 4.240283 \\
\hline 16. & 6 & teker teker & 1.544402 & 4.240283 \\
\hline 17. & 6 & yaz kış & 1.544402 & 4.240283 \\
\hline 18. & 6 & durup durup & 1.544402 & 4.240283 \\
\hline 19. & 5 & gece gündüz & 0.772201 & 1.766784 \\
\hline 20. & 5 & zaman zaman & 0.772201 & 1.766784 \\
\hline 21. & 4 & ara sıra & 3.474903 & 6.360424 \\
\hline 22. & 4 & bir bir & 3.474903 & 6.360424 \\
\hline 23. & 4 & çeşit çeşit & 3.474903 & 6.360424 \\
\hline 24. & 4 & sabah akşam & 3.474903 & 6.360424 \\
\hline 25. & 4 & sağa sola & 3.474903 & 6.360424 \\
\hline 26. & 4 & sık sık & 3.474903 & 6.360424 \\
\hline 27. & 4 & terli terli & 3.474903 & 6.360424 \\
\hline 28. & 4 & uzun uzun & 3.474903 & 6.360424 \\
\hline 29. & 4 & yalan dolan & 3.474903 & 6.360424 \\
\hline 30. & 3 & acı tatlı & 6.949807 & 9.540636 \\
\hline 31. & 3 & alev alev & 6.949807 & 9.540636 \\
\hline 32. & 3 & baştan başa & 6.949807 & 9.540636 \\
\hline 33. & 3 & biz bize & 6.949807 & 9.540636 \\
\hline 34. & 3 & çok çok & 6.949807 & 9.540636 \\
\hline 35. & 3 & gürül gürül & 6.949807 & 9.540636 \\
\hline 36. & 3 & iş güç & 6.949807 & 9.540636 \\
\hline 37. & 3 & kara kara & 6.949807 & 9.540636 \\
\hline 38. & 3 & kent kent & 6.949807 & 9.540636 \\
\hline 39. & 3 & kol kola & 6.949807 & 9.540636 \\
\hline 40. & 3 & köy köy & 6.949807 & 9.540636 \\
\hline 41. & 3 & mavi mavi & 6.949807 & 9.540636 \\
\hline 42. & 3 & omuz omuza & 6.949807 & 9.540636 \\
\hline 43. & 3 & renk renk & 6.949807 & 9.540636 \\
\hline 44. & 3 & sokak sokak & 6.949807 & 9.540636 \\
\hline 45. & 3 & şapur şupur & 6.949807 & 9.540636 \\
\hline 46. & 3 & şip şak & 6.949807 & 9.540636 \\
\hline 47. & 3 & topu topu & 6.949807 & 9.540636 \\
\hline 48. & 2 & ağır ağır & 20.07722 & 18.37456 \\
\hline 49. & 2 & baş başa & 20.07722 & 18.37456 \\
\hline 50. & 2 & boş boş & 20.07722 & 18.37456 \\
\hline Toplam & 308 & & 240.5405 & 375.6184 \\
\hline
\end{tabular}

Tablo 5'te sıklık derecesine göre ilk 50 ikileme görülmektedir. İkilemelerin (f: 308 ) toplam farklı ikileme içindeki yüzdeliği 240.5405; toplam ikileme içindeki yüzdeliği ise 375.6184’tür. Tablo değerlendirildiğinde "güle güle" (f: 40) birinci; "el ele" (f:27) ikinci; "kendi kendine" (f: 19) üçüncü sırada yer almaktadır. Bu değerlendirmeler tablodaki diğer ikilemeler için de yapılabilir. 
Tablo 6. Yerli çocuk tiyatrosu metinlerinde kullanılan atasözlerinin sıklık derecesi

\begin{tabular}{|l|c|l|}
\hline \multicolumn{1}{|c|}{ Sıra } & Atasözü Sıklığı & \multicolumn{1}{|c|}{ Atasözleri } \\
\hline 1. & 2 & Kaz gelen yerden tavuk esirgenmez \\
\hline 2. & 2 & Yalancının mumu yatsıya kadar yanar \\
\hline 3. & 1 & Atın ölümü arpadan olsun \\
\hline 4. & 1 & Bekleyen derviş muradına ermiş \\
\hline 5. & 1 & Bilmemek ayıp değil öğrenmemek ayıp \\
\hline 6. & 1 & Büyük balık küçük balı̆̆ı yutar \\
\hline 7. & 1 & Çekirge bir sıçrar iki sıçrar üçüncüsünde yakayı ele verir \\
\hline 8. & 1 & Damdan düşen damdan düşenin halini bilir \\
\hline 9. & 1 & Kaynayan kazan kapak tutmaz \\
\hline 10. & 1 & Korkunun ecele faydası yok \\
\hline 11. & 1 & Sakla samanı gelir zamanı \\
\hline 12. & 1 & Söz gümüşse sükût altındır \\
\hline 13. & 1 & Tilki erişemediği üzüme koruk der \\
\hline 14. & 1 & Yumuşak atın tekmesi sert olur \\
\hline Toplam & 16 & \\
\hline
\end{tabular}

Tablo 6'da çocuk tiyatrosu metinlerinde yer alan atasözleri gösterilmektedir. Buna göre "Kaz gelen yerden tavuk esirgenmez" (f:2) ve "Yalancının mumu yatsıya kadar yanar" (f:2) atasözleri ilk sıralarda yer almaktadır.

\section{Tartışma, Sonuç ve Öneriler}

1980-2008 yılları arasında yazıımış yerli çocuk tiyatrosu metinlerinin söz varlığını belirlemeyi hedefleyen bu çalışmanın 100.000 sözcükten oluşan havuzda toplam 7264 farklı sözcük belirlenmiştir. Söz varlığı öğelerinin toplamı açısından özel adlar en fazla sıklığa (3099) sahipken atasözleri (16) en az sıklıktadır. Farklılık sıklığı açısından ise deyimler (947), özel adlardan (886) daha fazla çeşitlilik göstermektedir.

Yerli çocuk tiyatrosu metinlerinde "Karagöz, Keloğlan, Hacivat" gibi özel adların yoğun sıklıkta kullanıldığı görülmektedir. Bu metinlere geleneksel oyun ve masal karakterlerinin yansıtıldığı söylenebilir. Değerlendirilmesi gereken diğer bir nokta ise "Atatürk", "Türkiye”, "Ankara”, "Anadolu”, "Mustafa Kemal Paşa" gibi özel adların sıklık düzeyidir. Bu özel adlar yerli çocuk tiyatrosu metinlerinin çocuğa bir şeyler öğretme yönüne göndermede bulunduğu söylenebilir.

"Hoş gel-" ve "hoşça kal-" gibi deyimlerin sıklık derecelerinin yüksek olması ise gündelik dilin tiyatro diline yansıması olarak yorumlanabilir. Ayrıca "el", "baş", "akıl" sözcükleriyle yapılan deyimlerin ağılıkta olduğu görülmektedir. Ders çalışmak (f:14) sözcük öbeği ise sıklık açısından dikkat çeken farklı bir deyimdir. Oyunların seslendiği yaş düzeyi göz önünde bulundurulduğunda (ilk ve ortaokul öğrencileri) bu deyimin bir ileti işlevi gördüğü söylenebilir.

Tiyatronun en önemli işlevlerinden biri de çocuklara dayanışmanın önemini sezdirmesidir. Tiyatro etkinliklerine katılan çocuklar birlikte bir iş başarmanın yanında dayanışmanın ve birbirlerine destek olmanın da önemini kavrayabilirler (Demirel ve ark., 2010, s. 276). Çocuklara sevme ve sevilme 
duygularını sezinleten, yaşama sevinci ve dayanışma isteği veren oyunlar onlar açısından en yararlı olanıdır (Gürel, Temizyürek ve Şahbaz, 2007) Bu belirlemelere koşut olarak yerli çocuk tiyatrosu metinlerindeki "el ele, omuz omuza, baş başa" gibi ikilemeler dikkat çekmektedir. Bu ikilemeler yerli çocuk tiyatrosu metinlerinin içeriğine ilişkin bir bilgi sunabilir. Dayanışmanın değerine gönderme yapan bu ikilemeler aracılığıyla "başarıya birlikte ulaşma" gibi iletiler çocuğa aktarılmak istenmektedir.

Baş (2006) tarafından yapılan çalışmada en fazla atasözünün öykülerde yer aldığı bulgulanmıştır. Bu yazınsal türde 9 toplam, 9 farklı atasözü bulunmuştur. Toplam atasözü kullanımı açısından ikinci sırada yer alan destan ve efsane türlerinde ise $8^{\prime}$ er atasözü kullanılmıştır. Farklı atasözü açısından efsaneler 7, destanlar 6 atasözüne sahipken masallarda toplam 4, farklı 4 atasözü vardır. Çocuk romanlarında ise hiçbir atasözü belirlenmemiştir. Söz konusu çalışmanın verileri ışığında yerli çocuk tiyatrosu metinlerindeki atasözlerinin sıklığı değerlendirildiğinde kullanılan atasözü sayısının az olmadığı söylenebilir. Tahkiyeli metinlerin (masal, destan, efsane, roman, hikâye) sözcük hazinesiyle çocuk tiyatrosu metinlerinde kullanılan kelime hazinesinin örtüşme düzeyi ise $\% 86,77656$ olarak tespit edilmiştir. Çocuk tiyatrosu metinlerindeki farklı sözcük sayısının (f: 7264) yalnızca masal türünün sahip olduğu sözcük hazinesinden (f: 6735) daha fazla olduğu söylenebilir. Roman (f: 8488), hikâye (8522), destan (f:7553) , efsane (f: 7468) türlerinde ise farklı sözcük sayısı daha fazla olduğu görülmektedir.

Söz varlığı üzerine gerçekleştirilecek çalışmaların amacına ulaşması için yapılacak diğer çalışmalardan biri de elde edilen verilerin çocukların sözcük hazineleriyle örtüşme düzeyini belirlemektir. Bu amaçla çocuk tiyatrosu metinlerindeki sözcük hazinesiyle I. kademe (Karadağ, 2005) ve II. Kademe (Kurudayıoğlu, 2005) öğrencilerinin sözcük hazineleri karşılaştırılmıştır. Elde edilen sonuçlara göre I. kademe öğrencilerinin kelime hazinesinin çocuk tiyatrosu metinlerindeki kelime hazinesiyle örtüşme düzeyi \%86,09788; II. kademe öğrencilerinin kelime hazinesinin çocuk tiyatrosu metinlerindeki kelime hazinesiyle örtüşme düzeyi ise $\% 87,85882$ olarak görülmüştür. Dolayısıyla II. kademe öğrencilerinin kelime hazinesinin, çocuk tiyatrosu metinleriyle örtüşme düzeyi daha yüksektir. Bu örtüşme düzeyi çalışma kapsamında incelenen çocuk tiyatrosu metinlerinin seslendiği yaş düzeyiyle ilişkilendirilebilir. Çünkü çocuk 12 yaşından itibaren metinli oyunlar sahnelemeye başlamaktadır (Şimşek, 2007, s. 178).

Çocuk edebiyatı ürünlerinin içerik, izlek, biçem ve söz varlığı açısından incelenmesi çocuk edebiyatının daha etkili olmasını ve amacına daha kolay ulaşmasına hizmet edebilir. Bu nedenle ileride gerçekleştirilecek çalışmalarda çocuk tiyatrosu metinleri kurguyu yapılandıran diğer öğeler (konu, karakter, dil ve anlatım, izlek ve ileti gibi) ve Türkçe öğretiminin amaçları kapsamında 
incelenebilir. Bununla birlikte çocuk tiyatrosu metinleri türlerine göre (gerçekçi, masalsı, fantastik) farklı açılardan değerlendirilebilir.

\section{Kaynaklar}

Aksan, D. (2003). Her yönüyle dil (Ana çizgileriyle dilbilim) (Cilt III). Ankara: Türk Dil Kurumu Yayınları.

Aksan, D. (2006). Ana dilimizin söz denizinde . Ankara: Bilgi Yayınevi.

Aksoy, Ö. A. (1936). Bir dili öğrenmek için en lüzumlu kelimeler ve bu kelimelerin belirtme usulü. Gaziantep: Gaziantep Dil Edebiyat Tarih Şubesi Yayınları.

Aksoy, Ö. A. (1998). Atasözleri sözlüğü. İstanbul: İnkılap Kitabevi.

Aksoy, Ö. A. (1998). Deyimler sözlügü. İstanbul: İnkılap Kitabevi.

Aslan, C. (2006). Yazınsal nitelikli çocuk kitaplarının çocuğun gelişim sürecindeki yeri. S. Sever (Ed.), II. Ulusal Çocuk ve Gençlik Edebiyatı Sempozyumu, Gelişimler, Sorunlar ve Çözüm Önerileri (s. 189-200). Ankara: Ankara Üniversitesi.

Aydın, T. (2016). Türk çocuk edebiyatı üzerine bir söz varlığı çalışması: atasözleri. Milli Eğitim(210), 425-445.

Baş, B. (2006). 1985-2005 yılları arasında çocuk edebiyatı sahasında yazılmış tahkiyeli metinlerin söz varlığı üzerine bir inceleme. Ankara: Gazi Üniversitesi Eğitim Bilimleri Enstitüsü, Yayınlanmamış Doktora Tezi.

Büyükhellaç, S. (2014). Ortaokul türkçe ders kitaplarındaki söz varlığının incelenmesi. Trabzon: Karadeniz Teknik Üniversitesi Eğitim Bilimleri Enstitüsü, Yayınlanmamış Yüksek Lisans Tezi.

Büyüköztürk, Ş., Akgün, Ö. E., Karadeniz, Ş., Demirel, F., \& Çakmak, E. K. (2010). Bilimsel araştırma yöntemleri. Ankara: Pegem Akademi.

Çetinkaya, Z. (2007). Masalların türkçe öğretimindeki yeri ve önemi. İzmir: Dokuz Eylül Üniversitesi Eğitim Bilimleri Enstitüsü, Yayınlanmamış Doktora Tezi.

Çiftçi, M. (1991). Bir grup yükseköğretim öğrencisi üzerinde kelime hazinesi araștırması. Ankara: Gazi Üniversitesi Sosyal Bilimler Enstitüsü, Yayınlanmamış Yüksek Lisans Tezi.

Demirel, Ş., Uludağ, M. E., Tozlu, N., Seven, S., \& Çeçen, M. A. (2010). Edebi metinlerle çocuk edebiyatında türler. Ş. Demirel (Ed.), Edebi metinlerle çocuk edebiyatı (ss. 147-366). Ankara: Pegem Akademi.

Ediskun, H. (2005). Türk dilbilgisi. İstanbul: Remzi Kitabevi.

Günay, D. V. (2007). Sözcükbilime giriş. İstanbul: Multilingual Yayınları.

Gürel, Z., Temizyürek, F., \& Şahbaz, N. K. (2007). Çocuk edebiyatı. Ankara: Öncü Basımevi.

Harıt, Ö. (1972). Samsun ve Ankara illerinin 6-7 yaş çocuklarında kelime hazinesi araştırması. Ankara: MEB Planlama-Araştırma ve Koordinasyon Dairesi Yayınları.

Karadağ, Ö. (2005). I. kademe öğrencilerinin kelime hazinesi üzerine bir araştırma. Ankara: Gazi Üniversitesi Eğitim Bilimleri Enstitüsü, Yayınlanmamış Doktora Tezi.

Karakuş, I. (2000). Türkçe-Türk dili ve edebiyatı öğretimi. Ankara: Sistem Ofset Yayınları.

Korkmaz, Z. (1992). Gramer terimleri sözlüğü. Ankara: Türk Dil Kurumu Yayınları.

Kurudayıŏ̆lu, M. (2005). ilköğretim II. kademe öğrencilerinin kelime hazinesi üzerine bir araştırma. Ankara: Gazi Üniversitesi Eğitim Bilimleri Enstitüsü, Yayımlanmamış Doktora Tezi.

Kuyumcu, N. (2000). Çocuk tiyatrosu. İstanbul: Mitos-Boyut Tiyatro Yayınları.

Kuyumcu, N. (2007). Çocuk tiyatrosu mu dediniz? İstanbul: Mitos-Boyut Tiyatro Yayınları. 
MEB. (2018). Türkçe dersi öğretim programı. Mart 10, 2018 tarihinde Milli Eğitim Bakanlığı Web Sitesi: http://mufredat.meb.gov.tr/Dosyalar/201812312239736-

T\%C3\%BCrk\%C3\%A7e\%20\%C3\%96\%C4\%9Fretim\%20Program\%C4\%B1\%202018.pdf adresinden alındı

Mert, E. L. (2009). Anadili eğitimi ve öğretimi sürecinde sözvarlığı belirleme çalışmalarının önemi ve "deyim" kazandırmaya yönelik etkinlik önerileri. Adıyaman Üniversitesi Sosyal Bilimler Enstitüsü Dergisi(2), 8393.

Mete, Ö. Ö. (2016). Sevim Ak'ın çocuk edebiyatı romanlarının sözvarlığı açısından çözümlenmesi. Ankara: Ankara Üniversitesi Eğitim Bilimleri Enstitüsü, Yayınlanmamış Yüksek Lisans Tezi.

Nas, R. (2002). Örneklerle çocuk edebiyatı. Bursa: Ezgi Kitabevi Yayınları.

Nutku, Ö. (1998). Oyun çocuk tiyatro. İstanbul : Özgür Yayınları.

Nutku, Ö. (2001). Dram sanatı (Tiyatroya giriş). İstanbul: Kabalcı Yayınevi.

Özbaşı, S. (2016). Zeynep Cemali'nin çocuk edebiyatı yapıtlarının sözvarlığı öğeleri açısından incelenmesi. Ankara: Ankara Üniversitesi Eğitim Bilimleri Enstitüsü, Yayınlanmamış Yüksek Lisans Tezi.

Özdemir, E. (2000). Sözlü-yazılı anlatım sanatı. İstanbul: Remzi Kitabevi.

Parlatır, İ. (2008). Atasözleri. Ankara: Yargı Yayınevi.

Parlatır, í. (2008). Deyimler. Ankara: Yargı Yayınevi.

Pars, V. B., \& Pars, C. B. (1954). Okuma psikolojisi ve ilkokuma öğretimi. İstanbul: Maarif Basımevi.

Sever, S. (2013). Çocuk ve edebiyat. İzmir : tudem Yayıncılık.

Sever, S., \& Karagül, S. (2014). Oğuz Tansel'in derleyip yazdığı masal kitaplarında yer alan sözvarlığı öğelerinin incelenmesi. Folklor/Edebiyat, 20(77), 173-188.

Şimşek, T. (2005). Teoriden uygulamaya okul tiyatrosu. Konya: Suna Yayınları.

Şimşek, T. (2007). Çocuk edebiyatı . Gümüşhane : Suna Yayınları.

Tavşancıl, E., \& Aslan, A. E. (2001). Sözel, yazılı ve diğer materyaller için içerik analizive uygulama örnekleri. İstanbul: Epsilon Yayıncılık.

Türk Dil Kurumu . (2005). Türkçe Sözlük. Ankara: Türk Dil Kurumu Yayınları.

Uzun, D. S. (2010). Ahmet Hamdi Tanpınarın "Saatleri Ayarlama Enstitüsü" adlı eserinin sözvarlığı ve eserin sözcükbilim açısından incelenmesi. Erzurum: Atatürk Üniversitesi Sosyal Bilimler Enstitüsü, Yayınlanmamış Doktora Tezi.

Vardar, B. (1980). Dilbilim ve dilbilgisi terimleri sözlüğü. Ankara: Türk Dil Kurumu Yayınları.

Yalçın, A., \& Aytaş, G. (2005). Çocuk edebiyatı. Ankara: Akçağ Yayınları.

Yalçın, S. K. (2005). Illköğretim 1. ve 5. sınıf türkçe ders kitaplarındaki söz varlığı unsurlarının eğitsel açıdan incelenmesi. Elazığ: Fırat Üniversitesi Sosyal Bilimler Enstitüsü, Yayınlanmamış Yüksek Lisans Tezi.

Yaman, E. (2004). Doğru ve etkili konuşma sanatı. Ankara: Gazi Kitabevi.

Yıldırım, A., \& Şimşek, H. (2005). Sosyal bilimlerde nitel araştırma yöntemleri. Ankara: Seçkin Yayınevi.

\section{Extended Abstract}

Introduction

The main material of Turkish language education is linguistic texts. The appropriateness of the texts to the child's meaning universe can help them to be more functional in language and literature teaching. Herewith, one of the first studies to be carried out is to evaluate vocabulary of such texts. 
The children's theater, which in itself is an artistic activity, helps the child to become more competent in aesthetic pleasure, character development and responsibility awareness. The child's language awareness mediates the acquisition of new skills, such as fluent and correct speech.

Linguistic regulation in children's plays is as important as other components. First of all, a text is required for theater play. Therefore, care must be taken in all stages starting from the construction of the text in order to obtain the desired outcome in terms of children in theater activities. Linguistically, the plays must be simple, vivid and appropriate to the stage and student level. Nevertheless, it should be in an easy style to pronounce, more economical than daily conversation, provide a development to each phase of the play.

\section{Method}

In this study, it was tried to determine the characteristics of the native children's theatrical text between 1980 and 2008 in terms of vocabulary. The population of this study is 100 native children's theater text written between 1980 and 2008. The sample of the study is a pool of 100,000 words randomly selected from the beginning, the middle and the end of these texts.

In this study based on qualitative research method, "categorical analysis technique" which is one of the types of content analysis is applied to analyze the data. "Words, special names, reiterative, idioms and proverbs" were chosen as the unit of analysis in the study. The main category of study is "vocabulary"; items such as "words, special names, reiterative, idioms and proverbs" compose subcategories. The vocabulary in the native children's theater texts was coded one by one and the frequencies were determined.

\section{Result and Discussion}

A total of 7264 different words were identified in the 100,000 word pool of this study which aims to determine the vocabulary of native children's theater texts written between 1980 and 2008 . The special names have the highest frequency $(f=3099)$ and the proverbs $(f=16)$ are the least frequency in terms of the sum of the vocabulary. In terms of frequency of difference, the idioms $(f=947)$ are more varied than the special names $(f=886)$.

It is seen that special names such as "Karagöz, Keloğlan, Hacivat, Vezir" are used intensively in the native children's theater texts. In these texts, it can be said that traditional play and fairy tale characters have an important place. Another point that should be considered is the special names such as "Atatürk", "Turkey", "Ankara", "Anatolia", "Mustafa Kemal Pasha" have high frequency. This level of frequency can be interpreted as an expression of the didactic orientation of the native children's theater texts.

The high frequency of idioms as "welcome" and "good-bye" can be interpreted as a reflection of the daily language to the theater language. It is also seen that the idioms formed by the words "hand", "head", "mind" have dominant frequency. Studying (lesson) is another different idiom that attracts attention in terms of frequency (f: 14). Looked the age level (primary and secondary school students) of the plays, it can be said that this idiom has a message function for children.

One of the most important functions of the children's theater is to grasp children the importance of cooperation. Children participating in theater activities are able to understand the importance of cooperation and supporting each other besides achieving a job. The plays that give children the feeling of love or being loved, the pleasure of life and the desire for cooperation are the most beneficial for them. Parallel to this, the reiterative such as "hand in hand, shoulder to shoulder, head to head" in the texts of native children's theater draw attention. Through these reiterative, which refer to the value of the cooperation, it is desired to convey to the child such messages as "coming together from a strong superior, reaching success together".

Proverbs are other component of vocabulary that should be discussed in terms of frequency in native children's theater texts. In other words, it can be said that the frequency of proverbs that used in the texts of the native children's theater are not insufficient when compared with the findings of different studies. 